\title{
Ahmad Amin Perspective of As-Sunnah
}

\author{
Atho'illah Umar \\ Kaprodi Ilmu Hadis UINSA Surabaya
}

\begin{abstract}
Moslems faith towards the position and autenthicity of hadits or sunnah in the period of the prophet SAW are unquestioned, because if ever they found anything that brought doubt or unclear they could easily confirm it to the prophet SAW. Contrary to the time after his passing until now, the issues of hadist has been complicated, which lead to opened the veil to see his being as a religious authority. As did by Ahmad Amin in his book Fajr al-Islam, who criticize some things in the hadist. According to him, the originality of the hadist after the passing of the prophet worth to be questioned. This paper trying to observe the thought of Ahmad Amin about Sunnah especially the one associated with the authencity of Sunnah after the passing of Rasulullah SAW and the critics of some ulama on his thought which against the flow of the concept of Sahabat's honesty which have become the Ijma' of most Ulama specifically muhaddithin.
\end{abstract}

Keywords : Ahmad Amin, Authencity, Sahabat's honesty.

\begin{abstract}
Abstrak
Keyakinan umat Islam terhadap posisi dan otentisitas hadits atau sunnah pada masa Nabi SAW tidak terdapat persoalan, karena jika mereka menemukan sesuatu yang meragukan atau yang belum jelas bisa langsung melakukan konfirmasi kepada Nabi SAW. Lain halnya pasca wafatnya beliau sampai sekarang, problematika hadits sudah sedemikian rupa, yang berujung kepada terbukanya tabir untuk melihat keberadaannya sebagai otoritas keagamaan. Seperti halnya dilakukan oleh Ahmad Amin dalam bukunya Fajr al-Islam, yang melakukan kritik terhadap beberapa hal tentang hadits. Menurutnya, orisinalitas hadits pasca wafatnya Nabi SAW patut dipertanyakan. Makalah ini mencoba meneropong pemikiran Ahmad Amin mengenai Sunnah terutama yang berkaitan dengan otentitas Sunnah pasca wafatnya Rasulullah SAW dan kritikan beberapa ulama' atas pemikirannya yang melawan arus konsep ke-adalah-an sahabat yang telah menjadi ijma' para ulama khususnya muhaddithin.
\end{abstract}

Kata kunci : Ahmad Amin, Otentitas, Ke-'adalah-an sahabat.

\section{A. Pendahuluan}

Hadits atau yang lazim juga disebut dengan sunnah merupakan sumber ajaran Islam setelah al-Qur'an, di dalamnya memuat pernyataan, pengamalan, pengakuan, dan segala hal ihwal tentang Nabi Muhamamd SAW. 


\section{Atho'illah Umar}

Posisi hadis atau sunnah yang tinggi tersebut dalam perundang-undangan Islam telah disepakati oleh seluruh umat Islam dari dahulu sampai sekarang. Sehingga dapat dikatakan bahwa percaya kepada sunnah adalah bagian dari iman di dalam agama dan menerima sunnah merupakan bagian dari menerima agama, sebagaimana terungkap dalam sebuah atsar yang populer:

$$
\text { ان هذا العلم دين فانظرو ا عمن نأخذون دينكم }
$$

"Sesungguhnya ilmu hadits ini adalah agama, maka periksalah dari siapa kalian mengambil agama itu".

Atsar tersebut menjelaskan dua hal yang penting yaitu; pertama, penilaian yang sangat tinggi terhadap sunnah, di mana ia diterapkan sebagai agama, sehingga menerima dan membenarkannya merupakan keharusan dalam beriman. Kedua, perlunya metode yang benar dan standard dalam melakukan penilaian dan penelitian terhadap kebenaran sunnah.

Berdasar pada perlunya suatu metode yang standard dan benar dalam penilaian dan penelitian sunnah, menunjukkan betapa besar keseriusan umat Islam dalam melestarikan sunnah sebagai sumber pokok ajaran agama. Hal ini dapat dilihat dari keseriusan dan kesungguhna para sahabat dalam mendapatkan, menjaga kemurnian sunnah. Para sahabat terobsesi untuk mengikuti segala apa yang mereka lihat dan dengar dari Nabi SAW. Mereka bertekad untuk mendata sunnah Rasulullah. Karenanya ada di antara mereka yang mengadakan giliran mengikuti majelis-majelis ilmu yang dilaksanakan Nabi SAW. Mereka yang tidak bisa menghadiri majlis ilmu Nabi SAW dapat memperoleh keterangan-keterangan 
melalui sahabat lain yang menyertai Nabi. Demikian itu mereka lakukan secara bergantian dan terus menerus.

Selanjutnya tradisi yang dilakukan para sahabat, kemudian dilanjutkan oleh para tabi'in (generasi setelah sahabat), berlanjut kemudian generasi berikutnya, dan akhirnya dapat dikatakan bahwa upaya menjaga kemurnian sunnah tidak pernah berhenti.

Dalam makalah ini, penulis akan mengangkat pandangan Ahmad Amin seputar otentisitas Sunnah dan pendapatnya tentang kritik sanad dan matan yang ia kemukakan dalam 3 karya fenomenalnya, Fajr al-Islam, Duha al-Islam dan Yaum alIslam.

\section{B. Biografi Singkat Ahmad Amin}

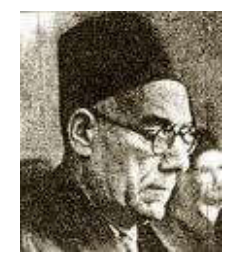

Nama lengkapnya adalah Ahmad Amin bin Ibrahim al-Tabbakh. Ia adalah seorang sastrawan, pemikir, sejarawan dan penulis dari Mesir. Dilahirkan di 'hayy almanshiyah' di Kairo tanggal 1 Oktober 1886 tepatnya empat tahun setelah masa penjajahan Inggris. Masa-masa ini termasuk masa yang sangat genting bagi Mesir modern. Ia menyadari bahwa kelahirannya pada tanggal itu adalah irha>s\}a>t (pertanda) bahwa ia akan ditakdirkan menjadi seorang guru, karena 1 Oktober adalah hari pertama tahun ajaran baru sekolah. 


\section{Atho'illah Umar}

Ia terlahirsebagai anak bungsu atau keempat dalam lingkungan keluarga yang terdidik dengan disiplin yang kuat. Dalam otobiografi yang yang dituis beberapa tahun menjelang wafat (1950), Amin mengatakan bahwa ia menimba ilmu pengetahuan di rumahnya sendiri, oleh ayahnya, tempat kediaman keluarga Ahmad Amin yang di setting seperti perpustakaan yang dilengkapi dengan kitab-kitab dalam banyak ilmu seperti: Fiqh, Tafsir, Hadits, Bahasa, Sejarah, Sastra Budaya, Nahwu, Sharaf, dan Balaghah. Dalam keseharian, waktunya dihabiskan untuk membaca kitab-kitab tersebut.

Setelah mendapatkan pendidikan di lingkungan keluarga, lingkungan bermain, kuttab (TPA), ia kemudian masuk ke pendidikan formal yaitu Ibtida'iyah "Walidah Abbas Pasha Pertama".. Kemudian ayahnya memasukkannya ke universitas al-Azhar Kairo, fakultas Syariah jurusan al-qad\}a>' al-syar'iy (Peradilan Agama). Ayahnya mengarahkannya ke mazhab Hanafi karena mazhab itulah yang biasa digunakan dalam peradilan agama.

Pada tahun 1911 ia lulus dengan mendapatkan ijazah kehakiman. Setelah lulus, ia belajar bahasa Perancis, kemudian Inggris dengan sangat serius; "aku tempuh segala cara untuk mewujudkan cita-citaku menguasai bahasa Inggris" dan ia pun berhasil mendapatkannya.

Lalu ia diminta untuk mengajar di almamaternya itu selama dua tahun. Kemudian pada tahun 1913 ia magang di kehakiman selama tiga bulan, setelah itu kembali lagi Al-Azhar untuk mengajar lagi. 
Pada tahun 1926, temannya, Dr. Taha Husain mempromosikannya ke Universitas Kairo untuk menjadi salah satu staf pengajar di fakultas Adab. Ia pun manjadi dosen tetap disana dan mengajar mata kuliah "al-naqd al-adabi" dan mendapat jabatan Prof. Muda tanpa doktor, hingga pada tahun 1939 ia diangkat menjadi Dekan di fakultas tersebut. Selain memangku jabatan, Ahmad Amin termasuk penulis yang produktif, bahkan ia dinobatkan sebagai ketua Komite Pengarang, Penerjemah dan Penerbitan selama 30 tahun. Jabatan inilah yang mendudukannya menjadi pengarang dan penulis yang terkemuka. Sebelum menjadi dekan ia berhasil menyelesaikan proyek bukunya "fajr al-Islam" dan "d\}uh\}a> alIslam".

Baru dua tahun menjabat dekan, ia mengundurkan diri sebagai sikap protes terhadap kebijakan Menteri Pendidikan, Dr. M. Husain Haikal yang memutuskan untuk memindahkan beberapa staf pengajar fakultas Adab ke Iskandariyah tanpa sepengetahuan Ahmad Amin selaku dekan. Ketika ia mengundurkan diri dan memutuskan untuk menjadi dosen biasa ia mengatakan saya lebih kecil dari guru dan lebih besar dari dekan. Ia merasa lega melepas jabatan dekan karena selama menjadi dekan, ia tidak bisa lagi produktif, masa-masa itu ia sebut sebagai masa paceklik ilmiah atau kemandulan berfikir.

Ketika menjadi dekan, ia sempat melakukan kunjungan di beberapa negara Arab dan Eropa, bahkan ia pernah mewakili Mesir dalam sebuah Konferensi 


\section{Atho'illah Umar}

Palestina yang diadakan di London. Keikutsertaan ini adalah berkat rekomendasi dari temannya Ahmad Lutfi Pasha al-Sayyid yang saat itu menjabat Menlu Mesir.

Bersama teman-temannya ia mendirikan "lajnah al-ta'lif wa al-tarjamah wa alnashr" pada tahun 1914 dan menjadi direktur seumur hidup. Ia juga pernah terlibat dalam lahirnya jurnal "al-Risalah" pada tahun 1936, lalu jurnal sastra mingguan "alThaqafah" (1939). Di beberapa halaman jurnal ini ia pernah memuat perbincangannya dengan beberapa pemikir masa itu seperti Zaki Najib Mahmud yang pernah mengangkat isu tentang turath arab dan kebangkitan barat.

Ia pernah menjadi direktur kantor kebudayaan dalam kementrian pendidikan tahun 1945. Pada tahun 1946 ia mendirikan "al-Jami'ah al-Sha'biyah" yang bertujuan untuk membumikan kebudayaan di masyarakat melalui ceramah-ceramah atau klub diskusi. Pada tahun itu juga ia mendirikan "ma'had al-makhtutat al-arabiyah" di bawah naungan Jami'ah al-Duwal al-Arabiyah. Ia pernah menjadi anggota korespondensi di "al-majma' al-ilmi al-arabi" Damaskus dan "al-majma' al-ilmi al-iraqi" sejak tahun 1926 M, juga menjadi anggota "majma' al-lughah al-arabiyah" sejak tahun 1940 M dan menjadi anggota "al-majlis al-a'la li dar al-kutub" pada tahun 1939 M.

Dunia politik menurut Amin tidak bisa dibedakan dengan "Patriotisme". Pengetahuannya tentang politik banyak ia dapat dari gurunya Atif Bik Barakat yang pernah membimbing Amin selama 18 tahun sebelum ia menjadi dosen. Patriotisme Amin sempat menarik perhatian Presiden Sa'ad Zaghloul terutama dari reportase yang ia tulis tentang keadaan Mesir pasca revolusi 1919. 
Ahmad Amin tidak suka terjun ke politik karena ia akui takut akan hukuman atau penjara. Dan politik menurutnya adalah penghalang bagi kebebasan berfikir.

Ahmad Amin termasuk pemikir produktif. Mayoritas karyanya adalah di bidang pemikiran, sastra, sejarah dan kebudayaan Islam. Karya-karyanya adalah sebagai berikut :

Fajr al-Islam, Duha al-Islam (3 juz), Dhur al-Islam (4 juz), Yaum al-Islam, Hayy bin Yaqadhan, Qamus al-adat wa al-taqalid wa al-ta'ayir al-Misriyah, Min zu'ama' al-islah, Kitab al-akhlaq, Hayati, Faid al-khatir (10 juz), al-Syarq wa al-gharb, Al-naqd al-arabi (2 juz), Harun al-Rashid, al-Sa'lakah wa al-fitwah fi al-Islam, Al-Mahdi wa al-mahdawiyah, Ila waladi, Qissah al-falsafah al-Yunaniyah, Qissah al-falsafah al-hadithah (2 juz), Qissah al-adab fi al-alam (4 juz), Mabadi' falsafah, Al-muntakhab fi al-adab al-arabi, Al-mufassal fi al-adab al-arabi, Al-mutala'ah al-tawjihiyah, dan Tarikh al-adab al-arabi.

Ahmad Amin menghembuskan nafas terakhirnya pada tanggal 30 Mei $1954 \mathrm{M}$ / 27 Ramadan 1373 H di usianya yang ke $68 .^{1}$

\section{Definisi Sunnah Menurut Ahmad Amin}

Sunnah : Segala perkataan, perbuatan, dan ketetapan Nabi SAW ${ }^{2}$. Kata 'sunnah' berasal dari kata 'sanna' yang berarti menggariskan, mengajarkan atau

\footnotetext{
${ }^{1}$ http://www.al-jazirah.com/2001/20010820/cu3.htm tgl akses : 11 / 2 / 2013 jam 05:47 pm, http://www.marefa.org/index.php/\%D8\%A3\%D8\%AD\%D9\%85\%D8\%AF \%D8\%A3\%D9\%85\%D9\%8A\%D9 \%86 akses 7/2/13, 7:41 pm, dan Ahmad Amin, Hayati, (Mesir : Kalimat Arabia, 2001)

${ }^{2}$ Ahmad Amin, Fajr al-Islam, (Beirut : Dar al-kitab al-arabi, 1969), 208
} 


\section{Atho'illah Umar}

meninggalkan sebuah kebiasaan atau cara hidup. Dari sini, maka makna 'sunnah' adalah cara atau kebiasaan yang baik. Dalam al-Qur'an disebutkan³ :

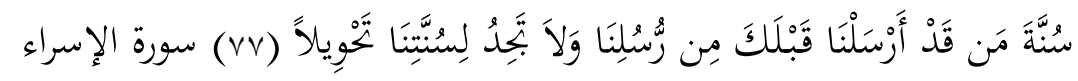

(Demikianlah) peraturan (Kami Yang tetap mengenai) orang-orang Yang telah Kami utuskan sebelummu dari Rasul-rasul kami; dan Engkau tidak akan dapati sebarang perubahan bagi peraturan Kami Yang tetap itu.

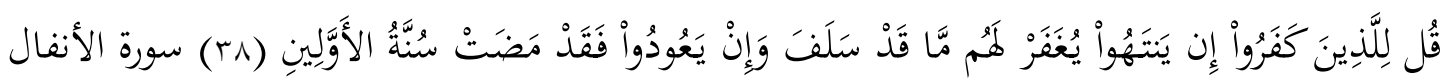

Katakanlah (Wahai Muhammad) kepada orang-orang Yang kafir itu, jika mereka berhenti (dari kekufurannya), nescaya akan diampunkan dosa mereka Yang telah lalu, dan jika mereka kembali lagi (ingkar maka Kami akan menyeksa mereka), kerana Sesungguhnya telah berlakulah kebinasaan orang-orang (yang kufur ingkar) dahulu kala.

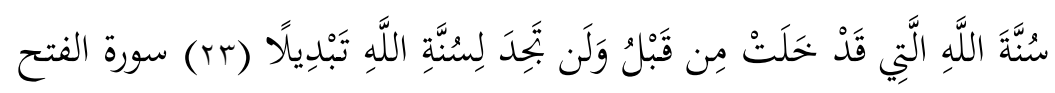

Kekalahan orang-orang Yang menentang Rasul Allah sudah tetap menurut) "Sunnatullah" (peraturan Allah) Yang telah berlaku semenjak dahulu lagi; dan Engkau tidak akan mendapati sebarang perubahan bagi cara dan peraturan Allah itu.

Dari ayat ini kemudian kaum Muslimin menyadur (iqtibas) kata sunnah dan

mereka gunakan untuk menyebut sunnah Nabi dan sahabatnya. ${ }^{4}$

${ }^{3}$ Ahmad Amin, Yaum al-Islam (Kairo : Maktabah al-Nahdah al-Misriyah, t.t), 12

${ }^{4}$ Ahmad Amin, Yaum al-Islam 13. Kata 'sunnah' dan 'hadith' sebenarnya sudah ada sejak zaman Rasulullah SAW, dan istilah ini bukan hal baru dari umat Islam baik dari sahabat maupun tabi'in setelah beliau wafat. Ini dapat dibuktikan melalui beberapa hadis yang menyebutkan dua istilah tersebut dari Rasulullah sendiri. Berikut adalah bukti-bukti pernyataan Nabi mengenai Sunnah dan Hadis :

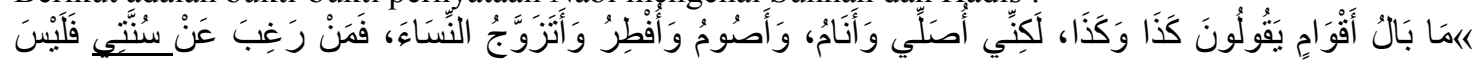

Lihat : Ahmad bin Syuaib al-Nasa'I, al-Sunan al-sughra, tahq: Abd Fattah Abu Ghaddah, jil. 6, cet-2 (Alepo : Maktab al-matbu'at al-Islamiyah, 1986), 60

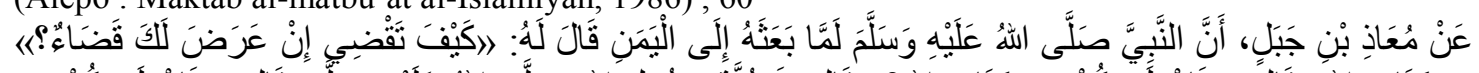

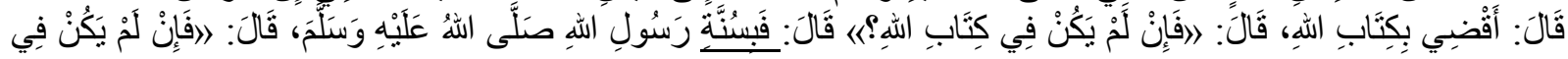


Dalam fajr al-Islam, Amin membedakan antara sunnah dan hadis. Sunnah hanya disandarkan kepada Rasulullah SAW sementara hadis disandarkan kepada Rasulullah SAW dan juga kepada sahabatnya. Tetapi dalam buku satunya, yaum alIslam, ia justru mengatakan bahwa hadis khusus untuk segala perkataan, dan perbuatan yang disandarkan kepada Rasulullas SAW meski dillakukan hanya sekali, meski diriwayatkan oleh satu orang. Sedangkan sunnah adalah segala yang disandarkan kepada para sahabat dan tabi' in ${ }^{5}$

Tugas hadis terhadap al-Qur'an menurut Amin, adalah sebagai pentafsil ayat yang mujmal, pentaqyid yang mutlaq, dan pentakhsis ayat yang umum. Misalnya Alqur'an hanya memerintahkan solat secara mujmal (global), dah hadis bertugas metafsil (merinci) mengenai kewajiban pelaksanaan solat tersebut mengenai waktunya, dan cara-cara pelaksanaannya. Misal lain adalah mengenai ayat yang mengharamkan khamr (al-Ma'idah: 90), mengenai definisi khamr, berapa kadar yang diharamkan, dan sebagainya adalah tugas hadis Nabi yang menjelaskan.

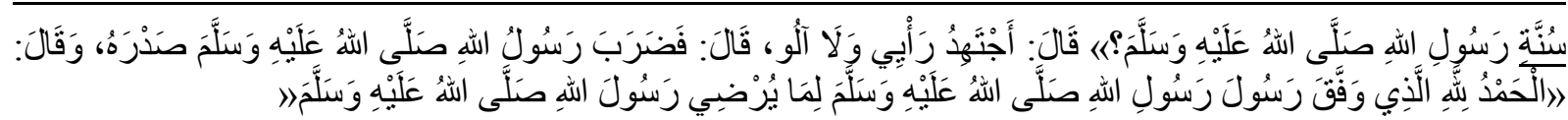
Lihat : Sulaiman bin Ahmad al-Tabrani, al-Mu'jam al-Kabir, tahq: Hamdi bin Abd Majid, jil. 20, cet-2 (Kairo : Maktabah Ibnu Taimiyah, 1994), 170

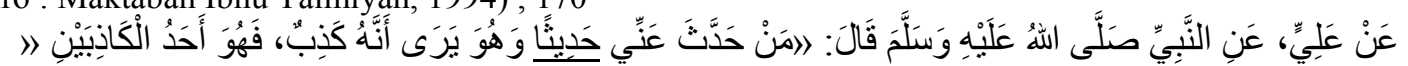

'barangsiapa yang meriwayatkan sebuah hadis (maudu' dan menisbatkan kepadaku) sedangkan dia tahu bahwa itu adalah maudu', maka ia (perawi) adalah salah satu dari dua pendusta (yang satu lagi adalah pencipta hadis maudu'. Teks-teks hadis marfu' ini menjadi bukti kuat bahwa istilah 'hadith' dan 'sunnah' sudah digunakan oleh Rasulullah SAW kemudian diikuti oleh semua sahabatnya. Lihat : Muhammad bin Yazid Ibn Majah al-Qazwini, al-Sunan, tahq: M. Fuad Abd Baqi, jil. 1 (Kairo : Dar Ihya' al-kutub al-arabiyah, t.t), 14

${ }^{5}$ Ahmad Amin, Fajr al-Islam, 208, Ahmad Amin, Yaum al-Islam 12 


\section{Atho'illah Umar}

Terkadang ayat turun untuk menjawab pertanyaan atau masaalah yang sedang dihadapi umat ketika itu, namun tidak semua ayat turun seperti itu. Kedua tipe ayat ini masing-masing membutuhkan bantuan hadis untuk menjelaskannya. ${ }^{6}$

Ahmad Amin tidak berseberangan dalam hal kehujjahan sunnah. Menurutnya, sunnah adalah salah satu sumber primer Islam dan menempati posisi kedua setelah al-Qur'an. Amin tidak setuju dengan kelompok 'inkar al-sunnah' yang ia pandang 'berani membuang' sunnah yang beranggapan bahwa mengamalkam al-Qur'an sudah cukup dan tidak perlu lagi tambahan amalan dari sunnah. Anggapan ini disalahkan oleh Amin karena menurutnya sunnah adalah pentafsir bagi ayat-ayat alQur'an yang masih mujmal, 'am, mutlaq, musykil dan mubham. Secara historis, Rasulullah adalah 'problem solver' bagi semua persoalan umat. Dari sunnah kita dapat mengetahui sejarah kehidupan sahabat, bagaimana mereka mengamalkan al-Qur'an, bagaimana mereka meneladani Rasulullah SAW, bagaimana mereka sukses membangun sebuah negara madani bersama Rasulullah SAW, belum lagi dari hadis kita juga bisa mengetahui semua perbuatan, kejadian dan peristiwa yang dilalui oleh Rasulullah SAW bersama para sahabatnya7

Ahmad Amin mengklasifikasikan hadis kepada tiga bentuk :

1- hadis-hadis akhlaq dan pendidikan. Kelompok hadis ini memuat hikmah, sopan santun, moral, nasehat-nasehat kepada sifat -sifat mulia seperi kejujuran, adil, ihsan,

\footnotetext{
${ }^{6}$ Ahmad Amin, Fajr al-Islam, 208

${ }^{7}$ Ahmad Amin, Yaum al-Islam, 12
} 
dan mencela sifat-sifat buruk seperti bohong, berbuat dhalim, kefasiqan, dan melakukan kerusakan (vandalisme).

2. hadis-hadis aqidah dan menjadi penegas atas konsep tawhid, sifat-sifat Allah, kenabian dan risalah, hari pembangkitan dan pembalasan sebagaimana yang telah dimuat al-Qur'an,

3. hadis-hadis $a h\} k a>m$. Khusus kelompok ini, ia mensyaratkan untuk sebuah hadis ahkam harus berstatus sahih. ${ }^{8}$

\section{Kodifikasi Hadis}

Menurut Ahmad Amin, pada masa Rasulullah SAW tidak ada satupun hadis yang dikodifikasi, Karena sejarah mencatat bahwa Rasulullah SAW hanya konsen untuk mengumpulkan al-Qur'an dan melarang para sahabat untuk menuis hadis beliau karena khawatir nanti akan tercampur dengan al-Qur'an yang sedang dalam proses pengumplan walaupun tidak secara massif.

Amin mengakui bahwa ada sejumlah sahifah (kumpulan atau catatan hadis) milik beberapa sahabat pada masa Nabi. Akan tetapi itu tidak berarti bahwa hadis sudah terkodofikasi pada masa itu ${ }^{9}$ sebaliknya proses tadwin terhadap hadis sama sekali belum direncanakan. Bahkan setelah Rasulullah SAW wafat pun, periwayatan hadis masih menggunakan cara lisan dan hanya mengandalkan kekuatan hafalan

\footnotetext{
${ }^{8}$ Ahmad Amin, Yaum al-Islam, 12

${ }^{9}$ Dalam yaum al-Islam, Ahmad Amin justru lebih dekat dengan pendapat mayoritas ulama hadis. Ia mengatakan 'wa qad budi-a jam'u al-hadithi fi hayat al-Rasuli thumma kathura zalika ba'dahu' (sungguh hadis pada masa Rasulullah sudah mulai dikumpulkan/ terkodifikasi - meskii sedikit - dan pada masa-masa setelah beliau wafat, kodifikasi hadis sudah dilakukan secara massif. Lihat : Ahmad Amin, Yaum al-Islam, (Kairo : Maktabah al-Nahdah al-Misriyah, t.t), hal. 13
} 


\section{Atho'illah Umar}

para perawi hadis, malahan beberapa sahabat ada yang tidak suka dengan banyaknya periwayatan hadis (sepeti Abu bakar, Umar,dan Ali) karena mereka khawatir akan dimanfaatkan oleh upaya pemalsuan atau mengganggu konsentrasi mereka dalam gerakan pengumpulan al-Qur'an. ${ }^{10}$

Namun begitu, permasalahan umat Islam semakin hari semakin kompleks dan bertambah. Dari sini mereka menganggap kebutuhan akan hadis tidak bisa ditawar lagi. Kegiatan penulisan hadis mulai dilakukan umat Islam baik secara individual maupun kolektif demi melayani kebutuhan sumber syareat kedua setelah al-Qur'an karena mengandalkan memori saja sudah tidak cukup, umat Islam kala itu membutuhkan mass storage selain otak manusia yang memberikan space lebih banyak untuk menyimpan hadis Nabi SAW. Khalifah-khalifah pada awal Islam sebenarnya sudah sering berunding untuk mengkodifikasi sunnah namun niat mereka tidak kesampaian karena kodifikasi al-Qur'an lebih diprioritaskan saat itu. Niat mereka ini baru bisa direalisasikan oleh salah satu khalifah dari Bani Umaayyah yang terkenal alim dan religius, Khalifah Umar bin Abdul Aziz.

Kodifikasi hadis yang dimulai pada penghujung abad pertama ini terus dilakukan dari tahun ke tahun, abad ke abad, hingga pada abad ke-3 kodifikasi hadis terutama kitab-kitab hadis primer sudah terkumpul secara sempurna dan mulai dilakukan penggandaan naskah. Konsentrasi ahli hadis pada saat itu adalah kepada sanad. Tidak ada satu kitab hadis pun yang tidak menyebutkan sanad secara

\footnotetext{
${ }^{10}$ Ahmad Amin, Fajr al- Islam, 208-210
} 
lengkap. Prinsip kesahihan hadis pada masa itu adalah tergantung pada kesahihan sanad, jika sanadnya sahih maka secara umum hadis itu pasti sahih. Betapapun ketatnya standar yang mereka terapkan, tetapi mereka tidak bisa menghalau arus isra $>$ iliyya $>t$ yang lolos dan mewarnai hampir semua kitab hadis.

Hal yang juga penting untuk dicatat, bahwa salah satu kekurangan ahli hadis klasik adalah kurang adanya perhatian mereka kepada kritik matan karena mereka sudah terkuras habis energinya untuk melakukan penelitian sanad yang menyita banyak waktu mereka sehingga tidak ada lagi ruang kosong untuk meneliti matan hadis.Pertanyaan-pertanyaan seputar matan hadis pada masa itu tidak pernah muncul ke permukaan, seperti bagaimana jika sebuah matan hadis bertentangan dengan fakta sejarah yang diketahui secara umum atau bertentangan dengan prinsip dasar al-Qur'an atau adanya matan hadis yang mengandung ancaman hukuman yang super berat terhadap pelanggaran yang sepele. ${ }^{11}$

Ahmad Amin menyesalkan keterlambatan kodifikasi sunnah yang menyebabkan hilangnya ribuan hadis bersamaan meninggalnya ratusan sahabat. Padahal jika di asumsikan bahwa setiap satu sahabat memiliki minimal satu hadis saja, sementara jumlah sahabat ketika Rasulullah wafat adalah 114000 jiwa, maka dengan angka itulah kita mendapatkan hadis. Kalau separuh saja dari mereka memiliki 10 hadis atau lebih maka tinggal dihitung saja betapa banyaknya hadis yang kita terima. Namun harapan itu memang sulit direalisasikan mengingat sahabat kala

\footnotetext{
${ }^{11}$ Ahmad Amin, Yaum al-Islam 14-15
} 


\section{Atho'illah Umar}

itu sudah tersebar di berbagai penjuru dunia dan tidak mungkin menghadirkan semuanya di Madinah untuk diambil hadisnya satu per satu.

Pada abad pertama, secara historis tidak ditemukan satu kitab pun yang berisi kumpulan hadis yang berhasil dikumpulkan oleh Muhammad Ibnu Syihab al-Zuhri maupun Abu Bakar bin Hazm. Justru kitab hadis pertama yang berhasil ditulis adalah kitab al-Muwatta' karya Imam Malik, murid al-Zuhri pada awal abad kedua. Malik menulis al-Muwatta' ini atas saran dari khalifah Abu Ja'far al-Mansur yang meneruskan pemikiran Umar bin Abdul Aziz. Khalifah Harun al-Rasyid juga pernah meminta Malik untuk menyetujui niatnya menggantung al-Muwatta' di dinding Ka'bah supaya menjadi pegangan amalan bagi semua umat Islam, namun Imam Malik menolak karena hal itu menurut Malik akan mencederai kebebasan mereka dalam bermazhab12

\section{E. Kemulaan Pemalsuan Hadis}

Ahmad Amin menganggap bahwa tidak adanya proses pengumpulan hadis pada masa Rasulullah atau pada masa-masa pertama kekhalifahan adalah menjadi penyebab banyaknya aksi pemalsuan hadis bahkan menurut Amin, pemalsuan hadis sudah mulai ada ketika masa Rasulullah SAW, adanya hadis ancaman neraka bagi pemalsu hadis ${ }^{13}$ menjadi indikasi kuat akan adanya upaya pemalsuan hadis pada

\footnotetext{
${ }^{12}$ Ahmad Amin, Fajr al- Islam, 221-222

${ }^{13}$ Terdapat beberapa redaksi tentang hadis ancaman neraka bagi pemalsu hadis ini. Menurut Ibn Salah, bahwa hadis ini berstatus Mutawatir karena diriwayatkan oleh puluhan sahabat yang jumlahnya mencapai 62 sahabat. Ini adalah satu-satunya hadis Mutawatir yang diriwayatkan oleh 10 sahabat yang dijamin surga (lihat Fu'ad Abd al-Baqi (tahq.) dalam Sunan Ibnu Majah, jil.1 (Kairo: Isa al-baby al-halabi, t.t), 13 . Variasi redaksi hadis ini antara lain :
} 
masa Nabi, dan setelah beliau wafat, upaya pemalsuan itu menjadi lebih mudah dan banyak dijumpai ${ }^{14}$

Pendapat ini menuai banyak kritikan dari ulama. Salah satunya adalah conter yang dikemukakan oleh Dr. Mustofa al-Siba'I bahwa pendapat ini justru melupakan fakta sejarah dan sedikitpun tidak menoleh kepada sababul wurud hadis ancaman pemalsuan hadis ini. Tidak satu pun riwayat yang menjadi sababul wurud hadis ini menyebutkan adanya peristiwa pemalsuan perkataan Nabi yang dilakukan oleh sahabat, sebab sahabat adalah sebuah komunitas yang telah dijamin ke-adalah-an nya oleh Allah dan Rasul-Nya menurut pendapat maoritas ulama'. ${ }^{15}$ Mengenai banyaknya hadis ancaman bagi pendusta ini menurut al-Sibai harus difahami bahwa

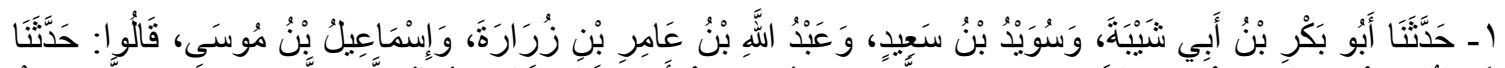

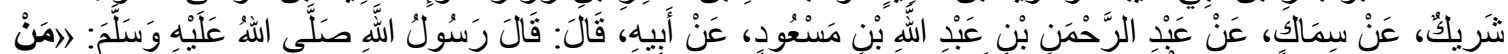

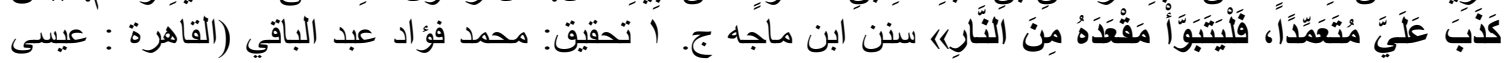

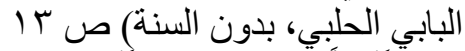

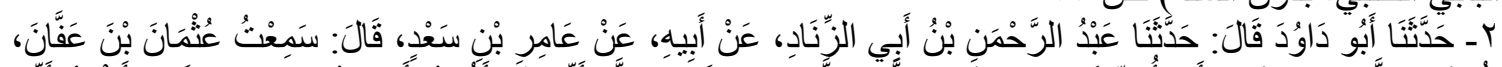

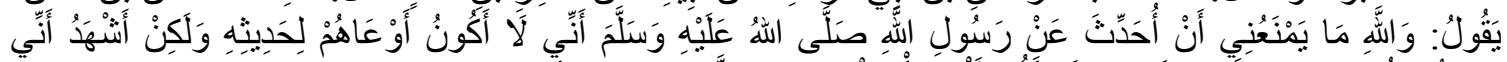

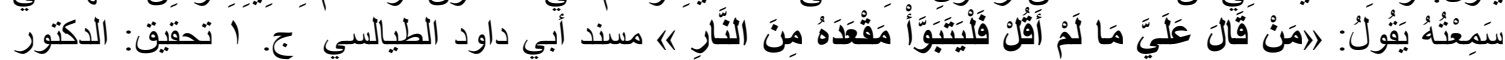

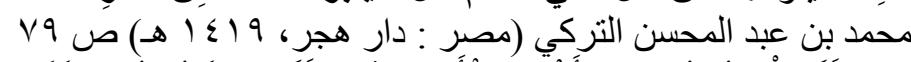

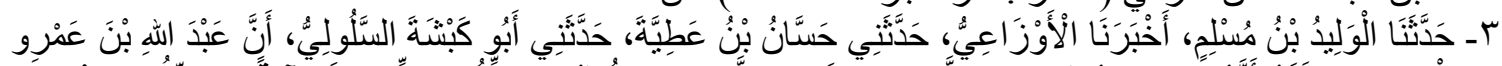

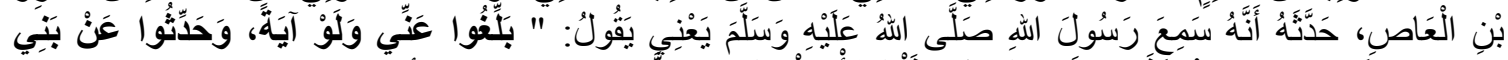

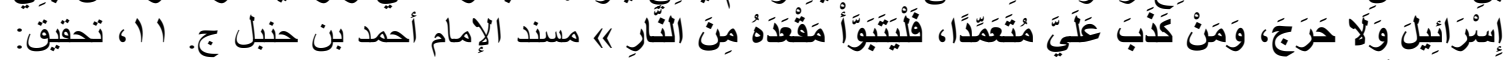

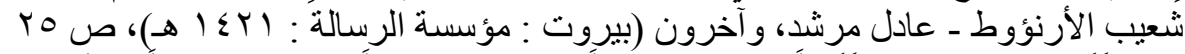

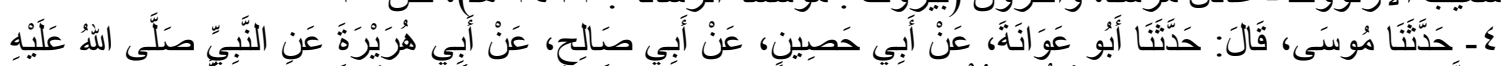

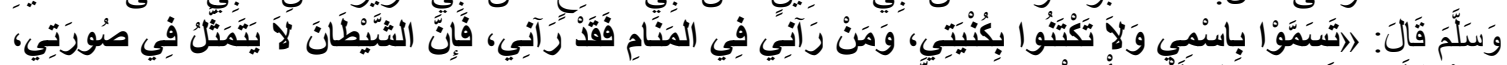

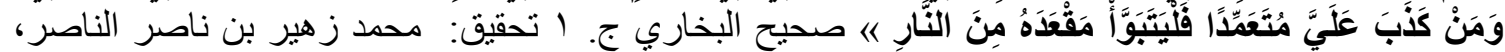

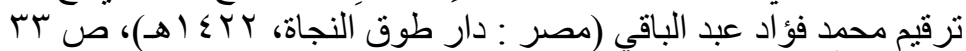

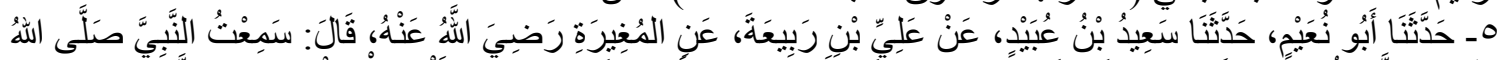

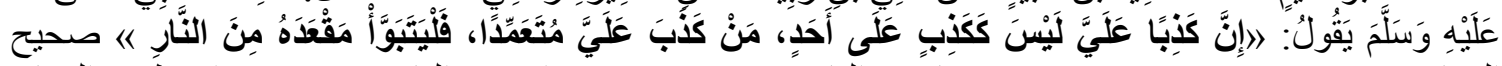

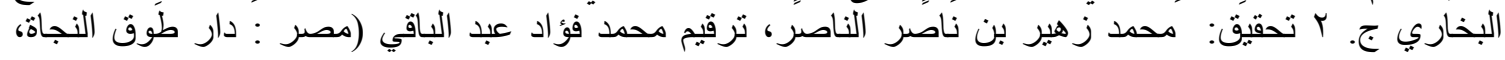

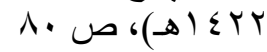

${ }^{14}$ Ahmad Amin, Fajr al-Islam, 211.

${ }^{15}$ Dr. Mustafa al-Siba'I, Al-sunnah wa makanatuha fi al-tasyri' al-Islamy, (Riyadl : Maktabah alWarraq, 1998), hal. 269 


\section{Atho'illah Umar}

Nabi SAW mengatakan demikian karena beliau dibukakan ilmu Allah sehingga beliau dapat meramalkan keadaan umat Islam sepeniggal beliau. Rasulullah mengetahui bahwa setelah beliau wafat, umatnya akan melakukan ekspansi ke beberapa belahan dunia dan pasti akan banyak orang dari berbagai suku dan ras yang masuk Islam. Ini akan berdampak terhadap penjagaan sunnah itu sendiri karena masalah sudah menjadi kompleks, manusia menjadi terkotak-kotak, kehidupan dalamsuasana politik tidak bisa dihindari dan masing-masing golongan saling berebut kepentingan. Keadaan inilah yang sudah dibaca jauh hari oleh Rasulullah SAW. Dengan demikian, maka hadis ancaman bagi pendusta itu sama sekali tidak mengindikasikan ada/banyaknya pendusta di masa Rasulullah SAW. ${ }^{16}$ Dengan logika yang sederhana saja, Rasulullah SAW adalah sosok yang sangat dicintai oleh para sahabatnya, sangat diagungkan, sangat disegani, mereka rela berkorban demi beliau, nyawa mereka tidak ada apa-apanya dibanding kehormatan dan kemuliaan beliau. Sungguh tidak bisa diterima oleh logika siapa pun jika ada salah satu (bahkan banyak) dari kalangan sahabat yang berani mengada-ngada (memalsukan) sabda Rasulullah SAW. Sahabat adalah manusia-manusia pilihan yang kecintaannya terhadap Rasulullah tidak diragukan lagi, mereka melindungi Rasulullah dengan sepenuh hati, tidak hanya melindungi dari serangan kaum kafir, mereka juga melindungi perasaan beliau sehingga mereka tidak akan terima jika ada yang mencaci beliau, namun justru Rasulullah SAW selalu menasihati sahabatnya

\footnotetext{
${ }^{16}$ Al-Siba'I, 267
} 
supaya selalu bersabar, mereka rela mengorban apa saja, harta dan jiwa mereka demi cinta mereka kepada Rasulullah SAW, bahkan mereka rela meninggalkan kampung halaman, sanak famili, dan mata pencaharian mereka ${ }^{17}$. Menjaga sunnah beliau juga merupakan manifestasi kecintaan kepada beliau dan ketaatan yang tiada bandingannya. Jika benar apa yang disampaikan oleh Ahmad Amin, maka sahabat pendusta itu pasti sudah bukan lagi sahabat, karena sahabat Nabi SAW tidak pernah berdusta $^{18}$, jika berdusta maka ia pasti akan masuk kepada golongan kaum munafiq yang pada saat itu memang tidak sedikit. Jika yang dimaksudkan Amin adalah mereka ini (kaum munafiq), maka mereka bukanlah sahabat Nabi melainkan musuh dalam selimut yang mengaku sahabat.

Imam Muhammad bin Shihab al-Zuhri adalah salah satu contoh figur yang menjadi sandaran utama dalam hadis Nabi. Beliau adalah gudangnya hadis. Beliau telah mengumpulkan sekitar 2000an hadis yang didapatkan dari ratusan tabi' iseperti Salim bin Abdullah bin Umar, Ali bin al-Husain bin Ali, Said bin al-Musayyib dan lain-lainnya. Salah seorang muridnya, Imam Malik berkata : Imam al-Zuhri tiada tandingannya di dunia ini, jika beliau berada di Madinah, maka tidak ada satu ulama' pun berani melafalkan hadis sebelum beliau meninggalkan Madinah ${ }^{19}$. Bisa kita bayangkan betapa besar penghormatan dan keseganan umat Islam terhadap sosok Imam al-Zuhri sebagai mahaguru hadis, sehingga para ulama'nya tidak berani

\footnotetext{
${ }^{17}$ M.M.Abu Zahw, al-Sunnah qabl al-tadwin, Lihat : M. Ajjaj al-Khatib, al-Sunnah qabla al-tadwin, cet3 (Beirut : Dar al-fikr, 1980), 190-191

${ }^{18}$ Ibnu Kathir berkata : Sahabat semuanya adil menurut Ahlussunnah wal jamaah. Lihat : Al-Hafiz Ismail Ibnu Kathir, Ikhtisar Ulum al-hadith, tahq: A.Shakir (Beirut : Dar al-kutub al-ilmiyah, t.t), 182

${ }^{19}$ M.M. Hasan Syurrab, al-Imam al-Zuhri Alim al-Hijaz, (Damaskus : Dar al-qalam, 1993), hal. 5
} 


\section{Atho'illah Umar}

melafalkan satu hadis pun di sekitar beliau (karena takut salah). Jika memang demikian, bisa kita bayangkan, berapa kali lipat keseganan dan penghormatan sahabat terhadap hadis Nabi di saat beliau masih hidup di tengah-tengah mereka?.

Dalam bukunya, Ahmad Amin menganalisa fenomena pemalsuan hadis yang terjadi di kalangan sahabat adalah disebabkan oleh lima faktor berikut :

1. Pertikaian politik antara Ali dan Abu Bakar, Ali dan Mu'awiyah, Abdullah bin Zubair dan Abd al-malik, kemudian antara khalifah-khlaifah bani Umayah dan Abbasiyah.

2. Perbedaan mazhab fikih dan kalam

3. Ketundukan orang alim kepada khalifah atau pejabat tinggi negara untuk mendapatkan kedekatan seperti yang dilakukan oleh Ghiyath bin Ibrahim terhadap khalifah al-Mahdi, namun sayang usahanya tidak berhasil karena khalifah al-Mahdi cukup alim dengan hadis Nabi SAW.

4. Adanya upaya dari para ulama untuk membumikan ibadah-ibadah atau amalanamalan tambahan seputar fada-il dan targhib wa tarhib, dan tidak ada kaitannya dengan hukum halal haram. Hal ini menggelitik mereka untuk memalsukan hadis dengan alih-alih tujuan kebaikan. Salah satu contoh yang dilakukan Nuh bin Abi Maryam bahwa ia telah mengarang sejumlah hadis mengenai keutamaan surat alQur'an, misalnya barang siapa yang membaca surat ' $x$ ' sebanyak ' $y$ ' kali maka ia akan mendapatkan pahala ' $z$ '. Hadis karangan Nuh ini seringkali ia sandarkan 
kepada para tokoh al-Qur'an seperti Ikrimah dari Ibnu Abbas, kadang juga ia sandarkan kepada Ubay bin Ka'ab.

5. Adanya opini masyarakat Muslim kala itu bahwa selain hadis tidak akan digubris atau didengar. Ilmu yang sebenarnya - terutama yang berkaitan dengan hukum halal haram - adalah yang disandarkan kepada al-Qur'an dan hadis. Jika tidak ada kaitan dengan keduanya, maka ia sama sekali tidak ada nilainya. Dari sini, timbullah keberanian dari beberapa intelektual Muslim yang ingin menyampaikan hikmah atau ilmu pengetahuan yang berasal dari Tradisi Bani Israel, India, Yunani atau Persia maka tidak ada jalan lain kecuali dengan 'menjadikannya' sebuah hadis terlebih dahulu supaya bisa diterima oleh masyarakat Muslim. Ini dapat dibuktikan dengan adanya beberapa riwayat hadis yang isro'iliyyah yang diambil dari Taurat dan Injil, hadis yang memuat hikmah India, Persia, atau filsafat Yunani kuno. ${ }^{20}$

Analisa tentang sebab-sebab terjadinya pemalsuan hadis ini, menurut hemat penulis sama sekali tidak ada hubungannya dengan keadaan sosiokultural masa Nabi SAW. Faktor pemalsuan hadis yang ia kemukakan ini tidak dapat menguatkan pendapatnya mengenai adanya pemalsuan hadis pada masa Rasulullah SAW. Kalaupun bisa dibenarkan, maka analisa faktor kemunculan ini hanya bisa ditarik ke masa-masa setelah Rasulullah wafat, yakni masa sahabat dan tabi'in.

\section{F. Ke-‘adalah-an sahabat}

${ }^{20}$ Ahmad Amin, Fajr al-Islam, 214-215 


\section{Atho'illah Umar}

Ahmad Amin menyayangkan, mengapa para kritikus hadis sepanjang zaman selalu menganggap semua sahabat itu adil? Dari sekian banyak peneliti tidak ada yang berani mengkritik sahabat apalagi memiliki praduga baahwa salah satu mereka pernah berdusta, padahal nyata diantara mereka sering terjadi jarh, saling mencela, saling tuduh berdusta, saling menjatuhkan terutama ketika mereka terlibat dalam berbagai kasus politik. Amin mengutip pernyataan al-Ghazali : keadaan 'adalah' mereka adalah terbatas pada masa-masa awal mereka dan berakhir ketika sudah terjadi pertikaian politik dan perang saudara antar mereka. Perubahan iklim yang terjadi dalam kehidupan sahabat mendorong kita untuk meneliti lebih dalam tentang keadaan mereka.Ia setuju dengan al-Ghazali yang mendefinisikan sahabat adalah orang yang lama bersama Nabi SAW.

Di sisi lain, Amin berpendapat bahwa sebagian sahabat meragukan kejujuran sahabat lainnya bahkan sampai menolak hadis yang ia riwayatkan. Kasus seperti ini banyak dijumpai dalam tradisi periwayatan pada masa sahabat, misalnya kritik Aisyah dan Ibnu Abbas terhadap Abu Hurairah, dan penolakan Umar terhadap riwayat Fatimah binti Qays. ${ }^{21}$

Dr. Mustafa al-Siba'I memberikan tanggapan atas ini, dan beliau katakan bahwa adanya saling kritik antar sahabat tidak berarti sebagian mereka tidak adil. Adapun jika ada mosi saling tidak percaya atau saling meragukan kejujuran yang lainnya, ini sama sekali tidak pernah dijumpai kecuali pada masa pecahnya fitnah,

${ }^{21}$ Ahmad Amin, Fajr al-Islam, 216-217 
lebih tepatnya sikap suka melempar vonis dusta dan caci mencaci di kalangan sahabat hanya muncul dari golongan syi'ah rafidah ${ }^{22}$ dan khawarij.

Adapun kritik Ibnu Abbas terhadap Abu Hurairah mengenai hadis tentang kewajiban wudlu' setelah membawa jenazah²3adalah disebabkan adanya pertentangan dengan dalil-dalil lain sehingga Ibnu Abbas menolak hadis itu. Adapun kritik A'isyah mengenai hadis tentang perintah mencuci tangan ketika bangun tidur ${ }^{24}$ dan kemudian Aisyah memberikan pertanyaan kritis 'bagaimana jika aku gunakan gayung?', versi yang benar adalah bahwa yang melempar pertanyaan kritis tersebut bukan Aisyah melainkan Qain al-Asyja'i dari kalangan Tabi'i sebagaimana diungkap oleh Ibnu Amir Haj25. Sedangkan hadis yang dibawakan oleh Ahmad Amin tidak ditemui di semua kitab hadis baik primer maupun sekunder. Menurut pengakuannya, hadis yang menyebutkan bahwa penanya kritis itu adalah Aisyah ada di dalam kitab Syarh musallam al-Thubut. ${ }^{26}$. Demikian bahwa dalil yang

\footnotetext{
${ }^{22}$ Al-Siba'i, 292

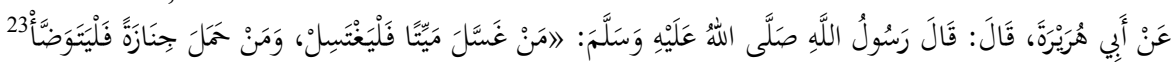

${ }^{24}$ Bandingkan dengan riwayat ini :

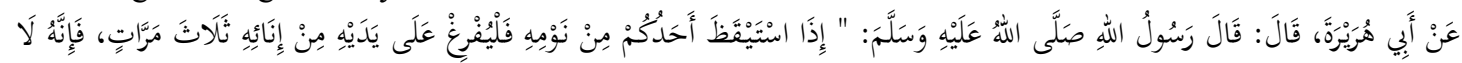

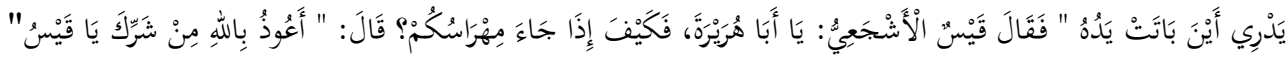

Lihat : Ahmad bin Hanbal al-Syaibani, al-Musnad, Juz 14, tahq: Syuaib al-Arnaut - Adil Murshid (Beirut : Muassasah al-Risalah, 2001), hal. 524

25 Lihat : M.M.M Ibn Amir Haj, al-taqrir wa al-tahbir, (Beirut : Dar al-kutub alilmiyah, 1983)

${ }^{26}$ Abdul Ali Muhammad bin Nizamuddin al-Laknawi, Fawatih al-Rahamut bi syarh musallam althubut, jil. 2 (Beirut: Dar al-kutub al-ilmiyah, 2002), hal. 177-178 


\section{Atho'illah Umar}

digunakan oleh Ahmad Amin tidak bisa dijadikan hujjah karena hadis yang ia gunakan tidak ditemukan dalam referensi kitab hadis ${ }^{27}$

Adapun penolakan Umar terhadap riwayat Fatimah binti Qays bukan berarti Umar menganggap Fatimah seorang pembohong. Umar menolak hadis Fatimah binti Qays karena ia bertentangan dengan dalil-dalil yang lebih kuat dari al-Qur'an maupun sunnah ${ }^{28}$. Riwayat yang berisi celaan Umar 'kita tidak tahu apakah dia jujur atau pembohong' tidak ditemui di dalam sahihain, justru di dalam sahihain menggunakan pernyataan 'kita tidak tahu apakah ia hafal atau lupa'. Dengan demikian, maka redaksi yang dikemukakan oleh Amin adalah syaz sementara redaksi yang Mahfudh adalah riwayat Muslim, Abu Daud dan Tirmidhi ${ }^{29}$.

\section{G. Abu Hurairah}

Abu Hurairah adalah perawi hadis dari kalangan sahabat yang paling banyak meriwayatkan hadis. Jumlah hadis yang beliau riwayatkan tercatat sebanyak 5374, sementara Abdullah bin Umar menempati posisi dibawahnya dengan periwayatan sebanyak 2630, kemudian Anas bin Malik sebanyak 2286, lalu Aisyah yang mencapai 2210, kemudian Abdullah ibnu Abbas sebanyak 1660, Jabir bin Abdillah 1540, Abu

Said al-Khudry sebanyak 1170 , lalu Abdullah bin Mas'ud sebanyak 484 hadis, Abdullah bin Amr bin al-Ash sebanyak 700 dan Ali bin Abi Talib sebanyak 537 hadis. Ini adalah daftar 10 perawi yang terbanyak meriwayatkan hadis.

\footnotetext{
${ }^{27}$ Al-Siba'I, hal. 333-335

${ }^{28}$ Al-Siba'I, 295

${ }^{29}$ Al-Siba'I, 294.
} 
Kenyataan Abu Hurairah sebagai perawi hadis terbanyak merupakan hal yang susah diterima oleh akal Ahmad Amin. Melihat masa interval beliau bersama Rasulullah SAW yang begitu singkat, yakni hanya sekitar 3 tahunan sebab beliau baru masuk Islam pada tahun $7 \mathrm{H}$. Sementara Aisyah adalah istri yang paling dicintai Rasulullah selalu mendampingi beliau selama masa beliau di Madinah hingga wafat. Abu Hurairah meninggal tahun $57 \mathrm{H}$ dan Aisyah tahun $58 \mathrm{H}$. Artinya mereka berdua sama-sama berumur panjang dan kesempatan untuk menggali hadis dari sahabatsahabat lain serta masa untuk meriwayatkannya sama-sama panjang. Dengan kesempatan yang sama ini ditambah keunggulan Aisyah dalam interval dimana beliau mendampingi Rasulullah setiap hari dan beliau mengetahui keadaan 'privat' beliau dimana tidak ada orang lain yang mengetahuinya kecuali beliau, dan ditambah lagi dengan tingkat intelektual beliau, maka atas dasar ini Ahmad Amin tidak bisa menerima jika Abu Hurairah menjadi perawi terbanyak, sebaliknya ini menjadi sasaran empuk bagi para pemalsu hadis untuk memalsukan hadis dan kesempatan bagi mereka untuk menyandarkan hadis-hadis palsu kepada Abu Hurairah sebanyak-banyaknya. ${ }^{30}$

Ahmad Amin juga mengkritik Abu Hurairah bahwa beliau sering meriwayatkan hadis yang beliau dapatkan tidak secara langsung dari Rasulullah SAW, melainkan dari sahabat lain. Amin mencontohkan hadis berikut ${ }^{31}$ :

\footnotetext{
${ }^{30}$ Ahmad Amin, Fajr al-Islam, 219-220

${ }^{31}$ Ahmad bin Hanbal al-Syaibani, al-Musnad, Juz 44, tahq: Syuaib al-Arnaut - Adil Murshid (Beirut : Muassasah al-Risalah, 2001), hal. 268
} 


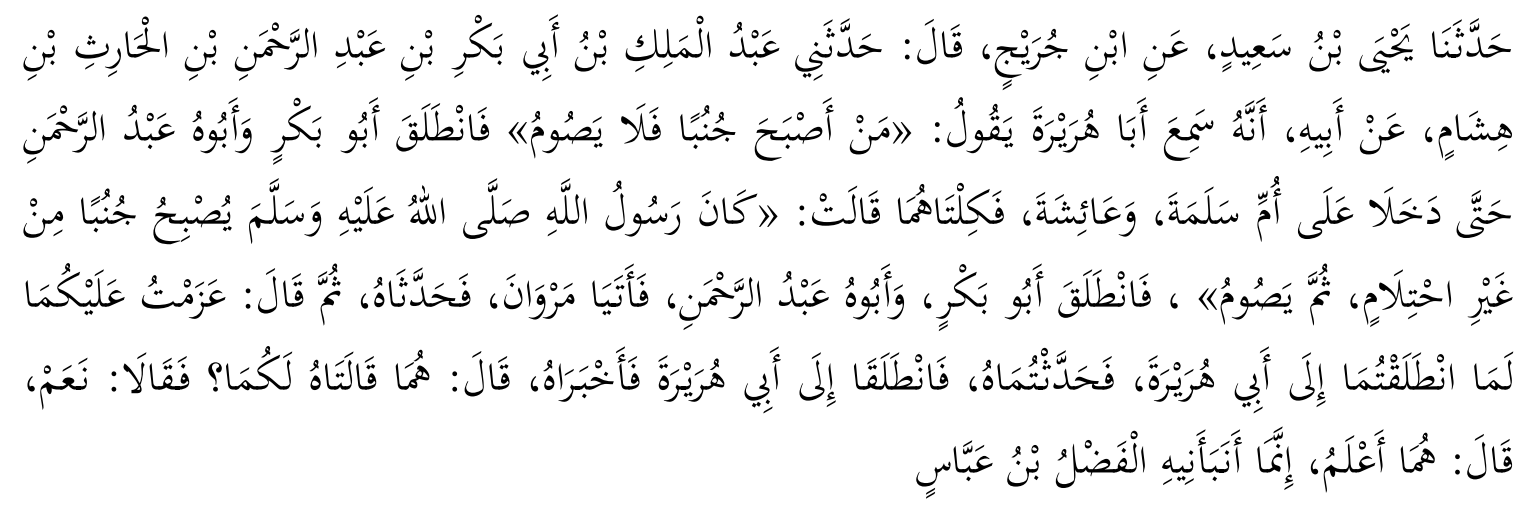

Dari Abu Bakar bin Abdurrahman bahwa ia mendengar Abu Hurairah berkata : "barangsiapa yang bangun subuh dalam keadaan junub maka tidak boleh berpuasa". Lalu Abu bakar dan ayahnya, Abdurrahman mendatangi Ummu Salamah dan Aisyah. Kedua Ummulmu'minin itu memberikan kesaksian "Rasulullah SAW (biasanya) bangun subuh dalam keadaan junub (bukan dari mimpi, tetapi dari jima') kemudian beliau berpuasa". Abu bakar dan ayahnya lalu mendatangi Marwan dan menceritakannya dan Marwan pun menyarankan untuk menceritakan hal itu juga kepada Abu Hurairah. Lantas mereka berdua pun menceritakannya kepada Abu Hurairah dan Abu Hurairah pun bertanya : benarkah kedua ummulmu'minin itu berkata demikian? Mereka berdua menjawab : benar. Mereka berdua lebih tahu, saya hanya menyampaikan apa yang saya dengar dari al-Fadl bin Abbas, terang Abu Hurairah.

Apa yang dipermasalahkan oleh Ahmad Amin tidak menjadi masalah buat ulama hadis karena walaupun Abu Hurairah mengambil hadis dari sahabat lain. Fakta ini juga banyak ditemukan pada kasus sahabat-sahabat junior (sighar) seperti Anas bin Malik, Ibnu Abbas dan ibnu Umar atau mereka yang terlambat masuk Islam seperti al-Barra' bin Azib dan Abu Hurairah. Kenyataan ini diakui sendiri oleh mereka, kasus seperti ini sering terjadi karena sahabat Nabi berjumlah sekian ratus bahkan ribuan dan mustahil kesemua sahabat itu bisa selalu mendampingi Rasulullah SAW atau menghadiri pengajian beliau setiap hari. Mayoritas sahabat mempunyai urusan dunia masing-masing, bekerja, berdagang atau bercocok tanam. Bahkan banyak juga diantara mereka yang tertinggal sangat jauh karena mereka baru 


\section{Al-Sunnah Perspektif Ahmad Amin}

saja masuk Islam atau mereka sudah muslim namun masih berusia dini. Abu Hurairah adalah salah satu contoh dari sekian banyak sahabat yang terlambat masuk Islam sehingga untuk menggali apa yang tertinggal, ia harus mendapatkannya dari sahabat lain yang mendengar langsung dari Rasulullah SAW. Bentuk periwayatan yang di dalam sanadnya menggugurkan satu atau dua sahabat sebelum Rasulullah dinamakan hadis Mursal. Namun jika yang menggugurkan itu adalah sahabat juga, maka dinamakan Mursal Sahabi. Terjadinya Mursal Sahabi disebabkan beberapa faktor di atas. Anas berkata : " tidak semua yang aku riwayatkan kepada kalian adalah aku dengar (langsung) dari Rasulullah SAW, tetapi kami sahabat Nabi tidak pernah saling berbohong satu sama lain”. Al-Barra' juga mengakui “ tidak semua hadis yang aku dapat aku dengar langsung dari Rasulullah SAW, sebagian hadis aku dengar dari beberapa sahabat dari Rasulullah SAW, itu karena kami disibukkan oleh gembalaan onta". Hukum Mursal Sahabi adalah sahih dan hadisnya bisa dijadikan hujjah menurut mayoritas ulama. Mengenai kehujjahan hadis Mursal, al-Nawawi berkata : Adapun Mursal sahabi, seperti periwayatannya tentang sesuatu yang dilakukan oleh Rasulullah SAW atau berbentuk periwayatan lainnya, sepengetahuan saya adalah disebabkan oleh tidak hadirnya perawi pada saat Rasulullah bersabda atau melakukan sesuatu baik karena umurnya terlalu muda kala itu atau karena terlambat masuk Islam, maka pendapat yang sahih adalah pendapat mayoritas ulama yang mengatakan bahwa hadis Mursal yang demikian itu bisa menjadi hujjah. ${ }^{32}$

\footnotetext{
${ }^{32}$ Al-Siba'I, hal. 339
} 


\section{Atho'illah Umar}

Berkenaan dengan hadis Abu Hurairah di atas, al-Baghawi mengemukakan pendapat lain yang mengatakan bahwa hadis yang disampaikan oleh Abu Hurairah tersebut adalah berdasar hukum lama pada awal-awal Islam dimana pada saat itu haram melakukan jima' pada malam-malam puasa. Ketika iman kaum muslmin semakin kuat, maka Allah memperbolehkan jima' pada malam puasa sebelum fajar terbit. Ketika fajar terbit, puasa boleh dilakukan walaupun belum melakukan mandi janabah. Fatwa Abu Hurairah ini adalah berdasarkan hukum lama yang ia dapatkan dari al-Fadl bin Abbas dan beliau tidak tahu kalau itu sudah di nasakh. Ketika mendengar apa yang diceritakan oleh Aisyah dan Ummu Salamah, maka Abu Hurairah meninggalkan fatwanya itu.

Ada lagi pendapat ketiga, bahwa hadis Abu Hurairah diatas adalah khusus bagi orang yang sedang melakukan jima' di waktu yang mendekati fajar, lalu ketika datang fajar, ia masih dalam keadaan berjima', maka ia tidak boleh melakukan puasa hari itu. ${ }^{33}$

\section{H. Konsep Jarah Ta' dil dan Kritik Hadis}

Al-Jarh wa al-ta' dil yang dilakukan oleh para ahli hadis menurut Amin sering dipengaruhi oleh faktor eksternal seperti karena adanya perbedaan atau fanatisme mazhab. Ini terbukti dari jarh ta'dil antara ahlussunnah dan syi'ah. Kaum Ahlussunnah menolak semua riwayat Ali yang diriwayatkan dari teman-teman dan pengikutnya, ahlussunnah hanya menerima hadis Ali dari riwayat Abdullah bin

${ }^{33}$ Al-Husain bin Mas'ud al-Baghawi, Syarh al-sunnah, tahq: Syuaib al-Arnaut, - M. Zuhair al-Shawish, Jil. 6 (Beirut-Damaskus : al-Maktab al-Islami, 1983) hal.281 
Mas'ud saja. Sikap yang sama, kaum syiah menolak semua riwayat sahabat kecuali dari jalur ahlul bait. ${ }^{34}$

Kedua, fokus jarh ta' dil yang dilakukan oleh ulama hadis hanya terbatas pada kritik sanad (kritik eksternal), kalaupun mereka melakukan kritik matan (kritik internal), paling-paling hanya seputar kesahihan matan itu dan sebatas meneliti apakah matan itu sahih atau maudu' ${ }^{35}$ Ahli hadis belum pernah meneliti matan apakah sesuai dengan realita atau tidak. ${ }^{36}$. Sebuah contoh hadis ${ }^{37}$ yang perlu dilakukan kritik matan (internal) sebagaimana dikemukakan Amin adalah :

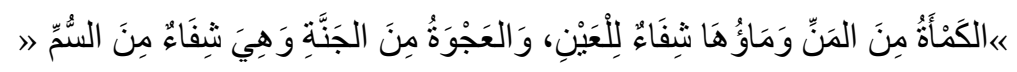
Kata Amin, pernahkah ulama hadis mengkritik dan menguji hadis ini dengan melakukan praktikum mengenai kam'ah? Apakah ia memang benar mengandung zat yang bisa menyembuhkan sakit mata? Begitu juga kurma ajwah, benarkah sudah terbukti bisa menjadi penawar racun? ${ }^{38}$

Terkait yang pertama, Al-Siba'I ingin meluruskan postulat yang dibangun oleh Amin, menurutnya kalangan ahlussunnah tidak pernah menolak riwayat seseorang hanya karena perbedaan mazhabnya. Para ahli hadis ahlussunnah melihat kredibilitas perawi hanya dari sisi kethiqahan yang terdiri dari kedlabitan dan adalahnya. Jika memang ada perawi syi'ah yang tidak diterima oleh ahlussunnah,

\footnotetext{
${ }^{34}$ Fajrul Islam, hal. 217

${ }^{35}$ Fajrul Islam, hal 217 dan Duha al-Islam, hal. 130

${ }^{36}$ Duha al-Islam, hal. 130

${ }^{37}$ Muhammad bin Isa al-Tirmizi, al-Sunan, tahq : M. Fuad Abd. Baqi - A. Syakir - Ibrahim Atwah, jil. 4 (Mesir : Mustafa al-baby al-halabi, 1975), $\varepsilon \cdot 1$

${ }^{38}$ Duha al-Islam, hal. 130-131
} 


\section{Atho'illah Umar}

maka itu mungkin dikarenakan perawi itu dikategorikan sebagai pelaku bid'ah atau pengajak kepada bid'ah. Atau ia dikategorikan sebagai perawi yang fasiq, dituduh berbohong dan sebagainya yang berkaitan dengan syarat adalah tadi. ${ }^{39}$

Adapun yang kedua, Abu Hurairah sendiri sudah membuktikan khasiat dari kam'ah itu, begitu juga al-Nawawi sudah mempraktekkannya bersama ahli pengobatan pada masanya dan berhasil menyembuhkan mata buta. Ibn al-Qayyim menambahkan, dari kalangan kedokteran muslim seperti Ibnu Sina, telah membuktikan bahwa di dalam kam'ah terdapat semacam senyawa yang berkhasiat mengobati sakit mata, dan jika dipakai celak, maka membuat penglihatan semakin terang dan menghilangkan rasa pedih. Dalam tadhkirahnya, Daud mengatakan, air $k^{\prime} m^{\prime} a h$ bisa menjadikan mata lebih putih. ${ }^{40}$

\section{Riwayat bi al-ma'na}

Amin menyayangkan keputusan para sahabat dan tabi'in yang membolehkan periwayatan bil ma'na dalam hadis dan menurut mereka, meriwayatkan hadis tidak harus menggunakan lafaz yang digunakan Rasulullah SAW.

Kebijakan ini menurut Amin, justru mempersulit generasi berikutnya karena dihadapkan pada pilihan kata yang bermacam-macam. Misalnya dalam ungkapan ijab, ada yang menggunakan 'zawwajtukaha' ada pula 'mallaktukaha' dan ada lagi 'khuz-ha' bima ma'aka min al-Qur'an. Karena redaksi yang bervariasi ini, ulama nahwu tidak pernah mau mengambil contoh-contoh susunan kalimat dari matan hadis. Ibn

\footnotetext{
${ }^{39}$ Al-Siba'I, 297

${ }^{40}$ Al-Siba'I, hal. 317
} 
al-Da-i' berkata "adanya pembolehan riwayat bil makna menjadi sebab utama ulama nahwu seperti Sibawaih tidak mau menggunakan permisalan dari hadis melainkan hanya dari ayat al-Qur'an atau syi'ir arab. Andaikata dahulu tidak ada kebijakan membolehkan riwayat bil ma'na, maka niscaya kefasihan kata-kata Nabi tetap terjaga, karena Nabi adalah orang arab yang paling fasih"

Selanjutnya, Amin menuduh ulama hadis sebagai biang pertikaian yang terjadi antara mereka dengan ulama fikih. Ini bermula dari celaan para ulama hadis terhadap ulama fikih yang jarang menggunakan hadis untuk menggali hukum (istinbat) dan ulama fikih hanya mengandalkan logika atau qiyas. Pertikaian ini tampak terlihat antara ulama Iraq (rasionalis) dan ulama Hijaz (tekstualis) pada masa Imam Malik dan Abu Hanifah. Pertikaian ini berlangsung cukup lama hingga ulama hadis jarang mau meriwayatkan hadis kepada ulama hanafiyah ${ }^{41}$

\section{J. Rasulullah dan Ijtihad}

Menurut Ahmad Amin, Rasulullah SAW tidak selalu bersabda atau bertindak berdasar wahyu, adakalanya beliau berbuat sebagai manusia biasa. Sebagai manusia biasa wajar jika Rasulullah SAW malakukan kesalahan dalam berijtihad, dan beliau memang pernah salah dalam berijtihad. Salah satu contoh, Nabi mendapat teguran dari Allah melalu sebuah ayat dari surat al-Anfal lantaran beliau melakukan kesalahan dalam berijtihad.

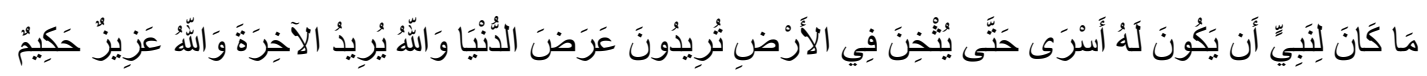

${ }^{41}$ Ahmad Amin, Duha al-Islam, hal. 133-134 


\section{Atho'illah Umar}

Tidaklah patut bagi seseorang Nabi mempunyai orang-orang tawanan kecuali untuk membunuh sebanyak-banyaknya di muka bumi. kamu menghendaki harta benda dunia (yang tidak kekal), sedang Allah menghendaki (untuk kamu pahala) akhirat. dan (ingatlah), Allah Maha Kuasa, lagi Maha Bijaksana ${ }^{42.43}$

Dalam hal ini, bisa juga kita jumpai dalam konsep Tradisi kenabian yang dikemukakan oleh Jasser Auda, bahwa Tradisi kenabian meliputi tiga kategori : 1) Nabi sebagai pembawa risalah kenabian (wahyu), 2) Nabi sebagai hakim dan pemimpin (sinergi teks-konteks / ijtihad) dan 3) Nabi sebagai manusia biasa ${ }^{44}$

Al-Qardawi ${ }^{45}$ menawarkan konsep kesyare'atan / kewahyuan Sunnah. Sunnah menurutnya terbagi menjadi 2 kategori, pertama kategori tasyri' (wahyu), dan kedua kategori ghair tasyri' (bukan wahyu).Untuk kategori yang kedua ini seorang muslim bebas memilih apakah mengikuti atau tidak. Baliau tidak mempersalahkan salah satu dari kedua aliran pada kategori kedua ini, karena masing-masing mempunyai alasannya sendiri sepanjang tidak melanggar sisi syare'at. Akan tetapi al-Qardawi mengemukakan bahwa segala yang berkaitan dengan kebiasaan dan adat Nabi adalah sangat berkaitan dengan adat dan budaya pada masa beliau sehingga beliau dituntut untuk menghormati adat dan budaya masyarakatnya ketika itu, misalnya budaya berpakaian, cara makan dengan jari, dan sebagainya. Dalam konteks ini Nabi dikategorikan sebagai manusia biasa.

${ }^{42}$ Al-Anfal : 67

${ }^{43}$ Ahmad Amin, Fajr al-Islam, 233

44 Jasser Auda, Maqasid al-shariah as philosophy of law : a Systems Approach, (London : The International Institut of Islamic Thought, 2007), 196

${ }^{45}$ Al-Qardawi, Al-Sunnah masdaran li al-ma'rifah wa al-hadarah (Kairo: Dar al-Syuruq, 2002), 14-24 


\section{Penutup}

Dari uraian di atas, dapat disimpulkan bahwa kegelisahan Ahmad Amin terhadap Sunnah membuktikan bahwa ia adalah seorang sejarawan kontemporer yang memandang otentitas Sunnah dari aspek sejarah. Beberapa pandangannya terhadap Sunnah ternyata bermacam-macam, ada yang sejalan dengan prinsip-prinsip ulum al-hadith seperti tentang kehujjahan Sunnah, aspek kewahyuan Sunnah, atau kritik sanad. Namun ada pula yang tidak sejalan dengan para ahli hadis seperti pandangan miringnya terhadap Abu Hurairah, mengkategorikan kaum munafiq dan pendusta dalam komunitas Sahabat yang berimplikasi kepada penolakan ijma' ulama bahwa semua Sahabat itu adil, bahwa kritik matan belum dilakukan pada abad kedua dan ketiga, kritiknya terhadap jarh ta'dil ahlussunnah dan syiah yang saling menolak periwayatan dari outsider karena perbedaan mazhab, padahal saling tolak hadis antara ahlussunnah dan syi'ah bukan karena perbedaan mazhab mealinkan karena perawi syi'ah di mata ahlussunnah adalah dikategorikan sebagai pelaku atau pendakwah bid'ah yang itu menjadi noda bagi keadalahan seorang perawi, ketidaksetujuannya dengan adanya riwayat bi al-ma'na yang menjadi sebab munculnya ambigu dalam teks hadis dan terakhir mengenai gagasannya dalam hal kewahyuan hadis Nabi, yakni tidak semua hadis Nabi adalah wahyu, karena Nabi juga seorang manusia biasa yang pastinya mustahil untuk tidak berperilaku sebagaimana manusia biasa dalam keadaan-keadaan tertentu. 


\section{Atho'illah Umar}

Demikian intisari dari pikiran-pikiran Ahmad Amin seputar Sunnah yang kita harapkan dapat menjadi inspirasi dan wawasan bagi kita semua sebagai ummatan wasatan, amin.

\section{Daftar Pustaka}

Ahmad Amin, Duha al-Islam, jil. 1 (Kairo:Maktabah al-Usrah, 2003) , Fajr al-Islam, (Beirut : Dar al-kitab al-arabi, 1969) Hayati, (Mesir : Kalimat Arabia, 2001) Yaum al-Islam (Kairo : Maktabah al-Nahdah al-Misriyah, t.t)

Ahmad bin Hanbal al-Syaibani, al-Musnad, Juz 14, tahq: Syuaib al-Arnaut - Adil Murshid (Beirut : Muassasah al-Risalah, 2001)

Ahmad bin Syuaib al-Nasa'I, al-Sunan al-sughra, tahq: Abd Fattah Abu Ghaddah, jil. 6, cet-2 (Alepo : Maktab al-matbu' at al-Islamiyah, 1986)

Al-Husain bin Mas'ud al-Baghawi, Syarh al-sunnah, tahq: Syuaib al-Arnaut, - M. Zuhair al-Shawish, Jil. 6 (Beirut-Damaskus : al-Maktab al-Islami, 1983)

Bukhari, al, Muhammad bin Isma'il, al-Jami' al-Sahih al-Musnad, jil. 1, tahq : M. Zuhair bin Nasir, (Mesir : Dar tuq al-najah, 1422)

Ibnu Kathir, al-Hafiz,Ikhtisar Ulum al-hadith, tahq: A.Shakir (Beirut : Dar al-kutub alilmiyah, t.t)

Jasser Auda, Maqasid al-shariah as philosophy of law : a Systems Approach, (London : The International Institut of Islamic Thought, 2007)

Laknawi, al,Abd al-Ali Muhammad bin Nizamuddin.Fawatih al-Rahamut bi syarh musallam al-thubut, jil. 2 (Beirut: Dar al-kutub al-ilmiyah, 2002)

M.M. Hasan Syurrab, al-Imam al-Zuhri 'Alim al-Hijaz, (Damaskus : Dar al-qalam, 1993)

M.M.Abu Zahw, al-Sunnah qabl al-tadwin, Lihat: M. Ajjaj al-Khatib, al-Sunnah qabla altadwin, cet-3 (Beirut : Dar al-fikr, 1980)

M.M.M Ibn Amir Haj, al-taqrir wa al-tahbir, (Beirut : Dar al-kutub al-ilmiyah, 1983)

Muhammad bin Isa al-Tirmizi, al-Sunan, tahq : M. Fuad Abd. Baqi - A. Syakir Ibrahim Atwah, jil. 4 (Mesir : Mustafa al-baby al-halabi, 1975)

Muhammad bin Yazid Ibn Majah al-Qazwini, al-Sunan, tahq: M. Fuad Abd Baqi, jil. 1 (Kairo : Dar Ihya' al-kutub al-arabiyah, t.t)

Mustafa al-Siba'I, Dr. Al-sunnah wa makanatuha fi al-tasyri' al-Islamy, (Riyadl : Maktabah al-Warraq, 1998)

Qardawi, al,Yusuf, Dr. Al-Sunnah Masdaran li al-ma'rifah wa al-hadarah, (Kairo: Dar alSyuruq, 2002

Sulaiman bin Ahmad al-Tabrani, al-Mu'jam al-Kabir, tahq: Hamdi bin Abd Majid, jil. 20, cet-2 (Kairo : Maktabah Ibnu Taimiyah, 1994)

Tayalisi, al, Abu Daud, al-Musnad, jil. 1, tahq: Dr. M. Abdul Muhsin al-Turki (Mesir : Dar Hajar, 1419) 
Al-Sunnah Perspektif Ahmad Amin

Web :

http://www.al-jazirah.com/2001/20010820/cu3.htm, akses11 / 2 / 2013 jam 05:47pm.

http://www.marefa.org/index.php/\%D8\%A3\%D8\%AD\%D9\%85\%D8\%AF_\%D8\%A 3\%D9\%85\%D9\%8A \% D9\%86, akses 7/2/13, 7:41pm. 